\title{
Tsunami hazard assessment in the Ionian Sea due to potential tsunamogenic sources - results from numerical simulations
}

\author{
G-A. Tselentis ${ }^{1}$, G. Stavrakakis ${ }^{2}$, E. Sokos ${ }^{1}$, F. Gkika ${ }^{1}$, and A. Serpetsidaki ${ }^{1}$ \\ ${ }^{1}$ University of Patras, Seismological Laboratory, Patras University Campus, Rio 26500, Greece \\ ${ }^{2}$ Institute of Geodynamics, National Observatory of Athens, 11810 Lofos Nymfon, Athens, Greece
}

Received: 3 February 2010 - Accepted: 16 April 2010 - Published: 12 May 2010

\begin{abstract}
In spite of the fact that the great majority of seismic tsunami is generated in ocean domains, smaller basins like the Ionian Sea sometimes experience this phenomenon. In this investigation, we study the tsunami hazard associated with the Ionian Sea fault system.

A scenario-based method is used to provide an estimation of the tsunami hazard in this region for the first time. Realistic faulting parameters related to four probable seismic sources, with tsunami potential, are used to model expected coseismic deformation, which is translated directly to the water surface and used as an initial condition for the tsunami propagation.

We calculate tsunami propagation snapshots and mareograms for the four seismic sources in order to estimate the expected values of tsunami maximum amplitudes and arrival times at eleven tourist resorts along the Ionian shorelines.

The results indicate that, from the four examined sources, only one possesses a seismic threat causing wave amplitudes up to $4 \mathrm{~m}$ at some tourist resorts along the Ionian shoreline.
\end{abstract}

\section{Introduction}

The western part of the Hellenic arc is one of the most seismically active areas in Greece and the entire Mediterranean region (Makropoulos and Burton, 1981; Jackson and McKenzie, 1988; Papazachos and Papazachou, 1997). This area has been repeatedly affected by large magnitude earthquakes (Fig. 1) that have caused severe destruction and human loss.

Large tsunami events require the presence of a thick water layer that can be found only in the oceanic domain, but it can also occur in small basins such as the Ionian Sea where many tsunamis have been reported during historical times.

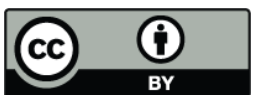

Correspondence to: G-A. Tselentis (tselenti@upatras.gr)
The Ionian region has an unexpected economic and tourist growth with an increase in coastal population and the development of large leisure areas during recent years, with many parts of coastal cities being a couple of metres above sea level, making them prospective targets of a large-scale disaster, even if the height of the tsunami wave is moderate. This situation requires urgent solutions for an effective risk management and mitigation plan. For this reason, it is essential to define the tsunami potential of the region and this study presents the first results of such an attempt.

The lack of direct records, however, makes the rigorous estimation of the expected tsunami amplitudes rather difficult, and the analysis of available documents remains, somehow, controversial.

Any attempt to assess a tsunami hazard, based on pure statistical methodologies, will not give reliable results because of data deficiency and because they use relationships linking earthquakes to tsunamis that may not be empirically well grounded. This means that alternative approaches to evaluate a tsunami hazard are called upon (e.g. Tselentis et al., 2006). Most often, a solution to the problem is searched for, in terms of a scenario that considers the largest events known to have hit the area of interest in the past history and to simulate these events through numerical modelling.

This is the approach used in the present investigation, focusing on the tectonic deformation mechanics of the potential tsunamigenic faults and their effect on the tsunami hazard in the region.

\section{Tectonic setting and tsunamigenic environment}

Western Greece (Ionian Islands and Western Peloponnese) represents one of the most seismotectonically active regions of the Mediterranean. It is part of a region of intense deformation located between two major lithospheric plates, the European plate and the African plate. The African plate is moving northwards relative to Eurasia at a rate of $10 \mathrm{~mm} /$ year (DeMets et al., 1990). Its leading edge is being subducted along the Hellenic Trench.

Published by Copernicus Publications on behalf of the European Geosciences Union. 


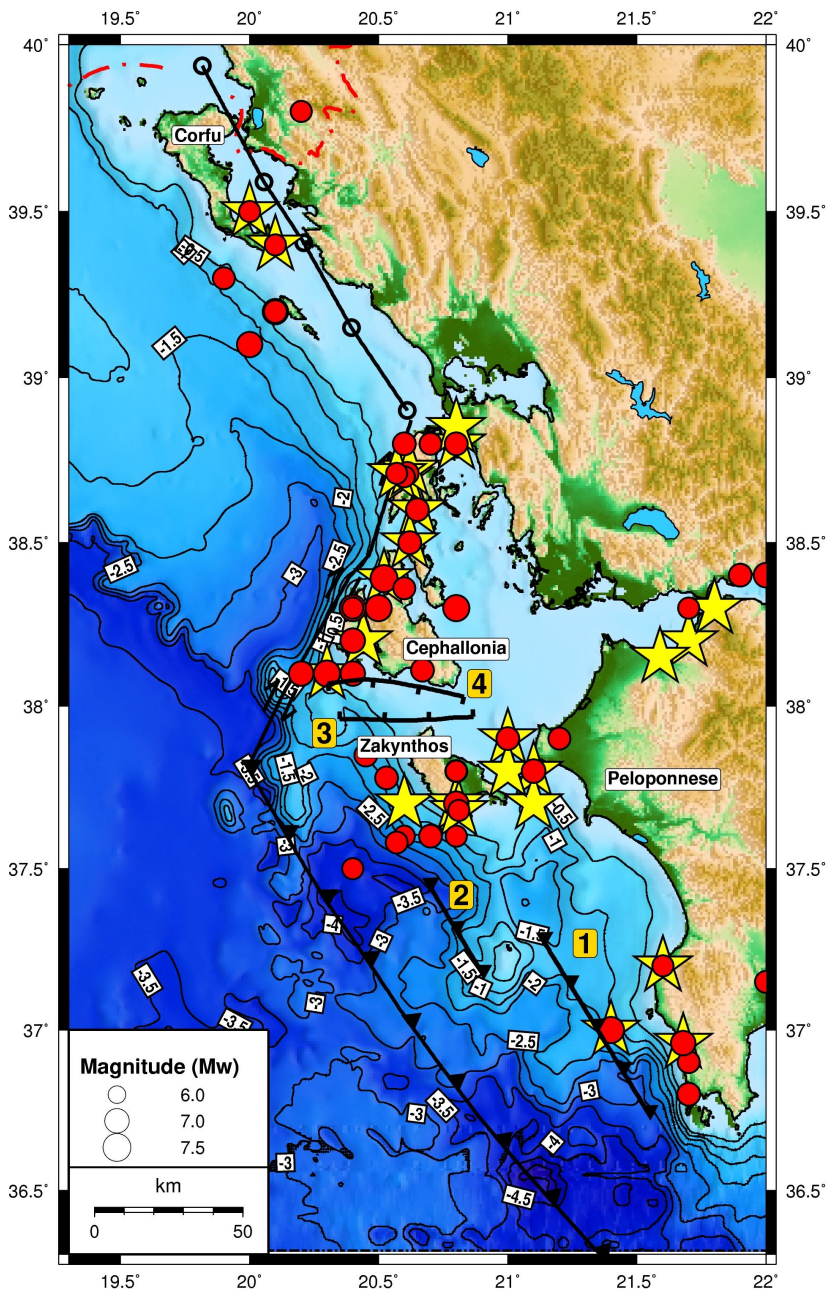

Fig. 1. Earthquakes with $M>6$ occurred along the Ionian Sea and the potential tsunamigenic sources (numbers in yellow squares) considered in the present investigation; contour depths are in $\mathrm{km}$. Stars, denote tsunami reported sides.

Seismological investigations (Jackson, 1994) and geodesy (Noomen et al., 1995) reveal that the relative motion across the Hellenic trench is NE-SW and greater than $5 \mathrm{~cm} / \mathrm{yr}$, while GPS measurements (Kahle et al., 1993) show a distinct movement of western Greece to the SW relative to Italy with an average of $120 \mathrm{~mm}$ between 1989 and 1993.

Seismotectonics of western Greece has been extensively studied (e.g. Haslinger et al., 1999). The major tectonic features, which set the Ionian Sea as an area of high seismicity are: the subduction of the African plate beneath the Aegean microplate along the western Hellenic trench, and the Cephallonia transfer fault at the northwestern end of the Hellenic arc, which is a major strike-slip fault that links the subduction boundary to the continental collision between the Apulian microplate and the Hellenic foreland.
Fault plane solutions, for several shallow and intermediate depth earthquakes in the Hellenic arc, have been published (Taymaz et al., 1990; Papazachos et al., 1991). Their results indicate that in the western part of the Hellenic arc, the thickness of the shallow seismogenic layer covers the upper $20 \mathrm{~km}$ of the crust. According to Papoulia et al. (2008), the area extending from Zakynthos to Messinia is limited by two main fault zones: the one striking NE-SW, offshore Kyllini, dipping to the south east, and the other striking EW, offshore Pylos, dipping to the north. According to Mariolakos et al. (1985) and Papanikolaou et al. (2007), these fault zones are active and are the offshore extensions of EW trending faults of Western Peloponnese.

The western Greece area has repeatedly suffered large offshore earthquakes (i.e. 1886 Philiatra M7.3, 1893 Zakynthos-Keri M6.5, 1899 Kyparissia M6.5, 1947 Pylos M7.0, and 1997 Gargaliani M6.6), which have caused damage and human loss (Papazachos and Papazachou, 1997). The presence of tsunamis have been observed a few times in the past, associated with offshore earthquakes (i.e. 1633 and 1886), affecting near field as well as remote coastal segments (Table 1).

The damage was minor from these events, due to the sparse population of the region in the early years. Today, a large earthquake along the Ionian sea fault system would damage coastal communities, and its effect would be enhanced by sea waves triggered from the seafloor displacement.

Taking into account the Ionian Sea tectonic regime and the tsunamogenic events depicted in Table 1, we have selected four potential seismic sources that could represent a tsunami hazard in the region (Fig. 1). The geographic location, strike, length and other parameters of each source were derived from existing fault maps, available reflection profiles and relevant seismological references and are presented in Table 2.

\section{Elastic dislocation modelling}

The traditional approach in modelling a tsunami generation is based on solving the hydrodynamic equations with boundary conditions at the seafloor corresponding to a static displacement caused by the earthquake source (e.g. Okal, 1982; Comer, 1984)

Offshore shallow earthquakes result in a seafloor coseismic deformation that can trigger a tsunami. Most studies of earthquake generated tsunamis use Mansinha and Smylie's (1971) formula or Okada's (1985) analytical formula based on elastic dislocation theory to predict seafloor displacement due to an earthquake and to model initial water displacement (e.g. Legg et al., 2004; Tselentis et al., 2006). This approach is being adopted in the present investigation.

In general, we assume that this coseismic deformation is much more rapid than the characteristic time involved in the wave propagation, and that the length scale of the seafloor 
Table 1. Possible, locally generated, tsunami along the western Hellenic arc fault system. $K_{\mathrm{O}}$ is the intensity of the wave and it refers to Sieberg's modified intensity scale (1932).

\begin{tabular}{|c|c|c|c|c|c|c|c|c|}
\hline No & Year & Month & Day & Lat/Lon & Region & $M$ & $K_{\mathrm{o}}$ & References \\
\hline 1 & 1622 & May & 5 & $37.60 / 21.00$ & Zakynthos Is., Ionian Sea & 6.6 & $?$ & $\begin{array}{l}\text { Ambraseys (1960), Galanopoulos (1960), } \\
\text { Antonopoulos (1980) }\end{array}$ \\
\hline 2 & 1633 & Nov & 5 & $37.70 / 20.80$ & Zakynthos Is., Ionian Sea & 7.0 & 2 & $\begin{array}{l}\text { Ambraseys (1962), Papazachos and } \\
\text { Dimitriu (1991), Papazachos et al. (1985), } \\
\text { Papazachos et al. (1986), Antonopoulos (1973) }\end{array}$ \\
\hline 3 & 1636 & Sep & 30 & $38.10 / 20.30$ & Kefalonia & 7.2 & 3 & $\begin{array}{l}\text { Papazachos and Dimitriu (1991), } \\
\text { Papazachos et al. (1985), Papazachos et al. (1986), } \\
\text { Antonopoulos (1973) }\end{array}$ \\
\hline 4 & 1723 & Feb & 22 & $38.60 / 20.65$ & Lefkada & 6.7 & $2+$ & $\begin{array}{l}\text { Ambraseys (1962), Galanopoulos (1961), Papazachos } \\
\text { and Dimitriu (1991), Papazachos et al. (1985) }\end{array}$ \\
\hline 5 & 1732 & Nov & & $39.40 / 20.10$ & Corfu & 6.5 & 2 & $\begin{array}{l}\text { Ambraseys (1962), Papazachos and Dimitriu (1991), } \\
\text { Papazachos et al. (1985), Papazachos et al. (1986), } \\
\text { Antonopoulos (1973) }\end{array}$ \\
\hline 6 & 1791 & Nov & 2 & $37.90 / 2100$ & Zakynthos Is., Ionian Sea & 6.8 & 3 & $\begin{array}{l}\text { Ambraseys (1962), Mallet (1850-1858), Papazachos } \\
\text { and Dimitriu (1991), Papazachos et al. (1985), }\end{array}$ \\
\hline 7 & 1804 & Jun & 8 & $38.10 / 21.70$ & Patras Gulf & 6.4 & 3 & $\begin{array}{l}\text { Ambraseys (1962), Hoff (1841), Galanopoulos (1960), } \\
\text { Papazachos and Dimitriu (1991) }\end{array}$ \\
\hline 8 & 1805 & Jan & 8 & $38.30 / 21.80$ & Patras Gulf & & $?$ & $\begin{array}{l}\text { Ambraseys (1962), Hoff (1841), Galanopoulos (1960), } \\
\text { Papazachos and Dimitriu (1991) }\end{array}$ \\
\hline 9 & 1820 & Mar & 17 & $38.80 / 20.80$ & Lefkada & & $?$ & Soloviev et al. (2000) \\
\hline 10 & 1820 & Dec & 29 & $37.80 / 21.10$ & Zakynthos Is., Ionian Sea & 6.9 & $3+$ & $\begin{array}{l}\text { Papazachos and Dimitriu (1991), } \\
\text { Papazachos et al. (1985), Papazachos et al. (1986), } \\
\text { Antonopoulos (1973) }\end{array}$ \\
\hline 11 & 1821 & Jan & 9 & $38.15 / 21.59$ & Patras Gulf & & 4 & $\begin{array}{l}\text { Ambraseys (1962), Mallet (1850-1858), } \\
\text { Galanopoulos (1938) }\end{array}$ \\
\hline 12 & 1825 & Jan & 19 & $38.70 / 20.60$ & Ionian Sea & 6.8 & 3 & Soloviev et al. (2000), Soloviev et al. (2000) \\
\hline 13 & 1835 & Jul & 12 & $37.70 / 21.10$ & Zakynthos Is., Ionian Sea & & 2 & Ambraseys (1962), Antonopoulos (1980) \\
\hline 14 & 1867 & Feb & 4 & $38.39 / 20.52$ & Kefalonia & 7.4 & 2 & $\begin{array}{l}\text { Papazachos and Dimitriu (1991), } \\
\text { Papazachos et al. (1985), Papazachos et al. (1986), } \\
\text { Antonopoulos (1973) }\end{array}$ \\
\hline 15 & 1867 & Apr & 10 & $38.20 / 20.44$ & Lixouri, Kefalonia & & 2 & Ambraseys (1960), Soloviev et al. (2000) \\
\hline 16 & 1869 & Dec & 28 & $38.85 / 20.80$ & Lefkada & 6.4 & 2 & Ambraseys (1962), Galanopoulos (1952) \\
\hline 17 & 1883 & Jun & 27 & $39.50 / 20.00$ & Ionian Sea & & 3 & $\begin{array}{l}\text { Ambraseys (1962), Galanopoulos (1960), } \\
\text { Antonopoulos (1980), Soloviev et al. (2000) }\end{array}$ \\
\hline 18 & 1886 & Aug & 27 & $37.00 / 21.40$ & W. Filiatra & 7.5 & 3 & $\begin{array}{l}\text { Ambraseys (1962), Vidal (1886), Ornstein (1889), } \\
\text { Galanopoulos (1960), Galanopoulos (1960b) }\end{array}$ \\
\hline 19 & 1889 & Jan & 22 & $37.20 / 21.60$ & Gulf of Kyparissia & 6.6 & 3 & $\begin{array}{l}\text { Papazachos and Dimitriu (1991), } \\
\text { Papazachos et al. (1985), Papazachos et al. (1986), } \\
\text { Antonopoulos (1973) }\end{array}$ \\
\hline 20 & 1893 & Apr & 17 & $37.68 / 20.81$ & Zakynthos Is., Ionian Sea & 6.4 & 2 & Ambraseys (1960) \\
\hline 21 & 1897 & Dec & & $37.80 / 21.00$ & Ionian Sea & & & Antonopoulos (1980) \\
\hline 22 & 1898 & Dec & 3 & $37.80 / 21.00$ & Ionian Sea & & 3 & $\begin{array}{l}\text { Ambraseys (1962), Antonopoulos (1980), } \\
\text { Soloviev et al. (2000) }\end{array}$ \\
\hline 23 & 1899 & Jan & 22 & $37.20 / 21.60$ & Kyparissia & 6.5 & 3 & Ambraseys (1962), Mitzopoulos (1900), \\
\hline 24 & 1914 & Nov & 27 & $38.72 / 20.62$ & Lefkada & 6.3 & 4 & $\begin{array}{l}\text { Ambraseys (1962), Galanopoulos (1952), } \\
\text { Papazachos and Dimitriu (1991) }\end{array}$ \\
\hline 25 & 1915 & Aug & 7 & $38.50 / 20.62$ & Lefkada & 6.7 & 3 & $\begin{array}{l}\text { Ambraseys (1962), Galanopoulos (1960), } \\
\text { Galanopoulos (1952), Papazachos and Dimitriu (1991) }\end{array}$ \\
\hline 26 & 1947 & Oct & 6 & $36.96 / 21.68$ & W. Pylos, Methoni & 7.0 & 3 & $\begin{array}{l}\text { Ambraseys (1962), Galanopoulos (1952), } \\
\text { Papazachos and Dimitriu (1991) }\end{array}$ \\
\hline 27 & 1948 & Apr & 22 & $38.71 / 20.57$ & Lefkada Vassiliki & 6.5 & 3 & $\begin{array}{l}\text { Ambraseys (1962), Galanopoulos (1955), } \\
\text { Galanopoulos (1960), Papazachos and Dimitriu (1991) }\end{array}$ \\
\hline
\end{tabular}


Table 2. Fault parameters of the selected potential tsunamigenic sources used for the numerical simulation (FAUST database, Stucchi et al., 2001; Papazachos and Papazachou, 1997).

\begin{tabular}{lllllllllll}
\hline Id & $\begin{array}{l}\text { Fault } \\
\text { Name }\end{array}$ & Type & $\begin{array}{l}\text { Strike } \\
(\mathrm{deg})\end{array}$ & $\begin{array}{l}\text { Dip } \\
(\mathrm{deg})\end{array}$ & $\begin{array}{l}\text { Rake } \\
(\mathrm{deg})\end{array}$ & $\begin{array}{l}\text { Slip } \\
(\mathrm{cm})\end{array}$ & $\begin{array}{l}\text { Length } \\
(\mathrm{km})\end{array}$ & $\begin{array}{l}\text { Width } \\
(\mathrm{km})\end{array}$ & $M_{\mathrm{W}}$ & $\begin{array}{l}\text { Depth } \\
(\mathrm{km})\end{array}$ \\
\hline 1 & Filiatra & thrust & 329 & 30 & 121 & 275 & 70 & 45 & 7.5 & 2 \\
2 & Zakynthos & thrust & 329 & 22 & 120 & 107 & 35 & 22 & 7 & 2 \\
3 & Cephalonia South & normal & 270 & 60 & -90 & 42 & 37 & 13 & 6.5 & 2 \\
4 & Cephalonia North & normal & 110 & 60 & -90 & 107 & 40 & 22 & 7.1 & 2 \\
\hline
\end{tabular}
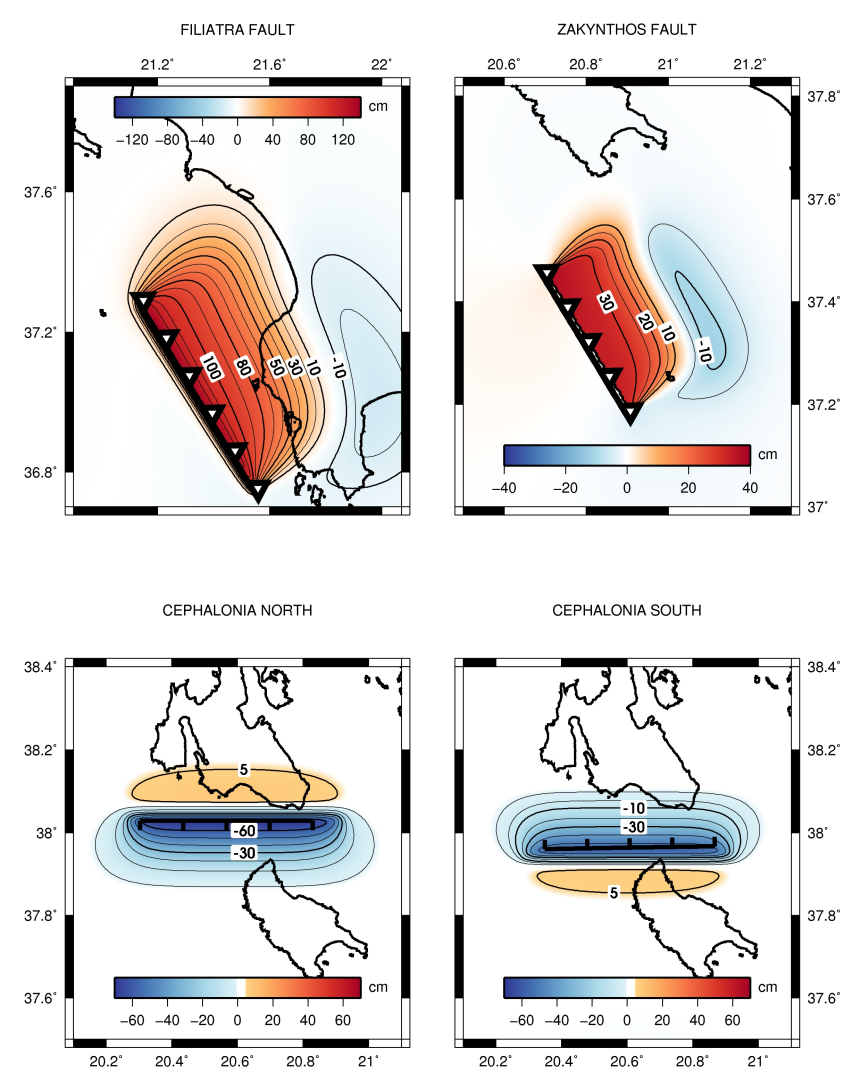

Fig. 2. Sea bottom expected displacements due to the activation of the four sources considering the source parameters depicted in Table 2 .

deformation is much larger than the water depth. This allows us to define the initial subsurface deformation as being equal to the coseismic vertical displacement.

Table 2 presents the source models of the selected tsunamigenic sources used in the present study. The corresponding fault slips $u$, were determined from (Papazachos and Papazachou, 1997)

$\log u=0.82 M-3.71$

where $M$ is the magnitude.
Table 3. Sea bottom deformations due to the activation of the four potential sources.

\begin{tabular}{llll}
\hline Id & Fault Name & \multicolumn{2}{r}{$\begin{array}{r}\text { Vertical Calculated Displacement } \\
(\mathrm{cm})\end{array}$} \\
\cline { 3 - 4 } & & $\begin{array}{l}\text { Min } \\
\text { (Subsidence) }\end{array}$ & $\begin{array}{l}\text { Max } \\
\text { (Uplift) }\end{array}$ \\
\hline \multirow{2}{*}{1} & Filiatra & -19 & 135 \\
2 & Zakynthos & -12 & 39 \\
3 & Cephalonia South & -56 & 7 \\
4 & Cephalonia North & -67 & 8 \\
\hline
\end{tabular}

Initial conditions for tsunami propagation from all four selected potential seismic sources are determined from the static displacement field by using the three-dimensional elastic boundary element method algorithm POLY-3D (Thomas, 1993), assuming a Poisson's ratio of 0.25 .

Next, we calculate the sea-bottom strain field for each one of the four fault scenarios considering the source characteristics depicted in Table 2. The obtained results are shown in Fig. 2, and the corresponding vertical displacements are presented in Table 3.

Calculations of seafloor displacements are made assuming a homogeneous elastic structure (Poisson's solid). The effect of elastic inhomogeneity on surface displacements and tsunami waveforms is not included in this study. The near shore tsunami amplitude values predicted in this investigation ignore the possibility of large submarine landslides being triggered by the earthquake, and this study focuses on the tectonic sources only.

\section{Tsunami modelling}

The deformation field, obtained above, is used as an initial condition of the hydrodynamic computation. This constitutes a legitimate approximation, since the deformation of the seafloor always takes place more rapidly than the tsunami waves can propagate the sea surface deformation away from the source region. 
Numerical simulations are useful tools for analysing tsunami propagation and coastal amplification. The tsunami waves, generated by earthquakes, depend on the size and the impact of the source mechanism on the displaced water. Despite the differences in the underlying physics of wave propagation in the sea and solid earth, the tsunami wave field emanating from an earthquake source can be thought of as an extension to the seismic wave field (Okal, 1982).

There are at least three kinds of tsunami propagation and inundation models in common use among tsunami scientists: nonlinear shallow-water models (NSWMs), Boussinesq-type long-wave models, and complete fluid dynamics models, which all stem from the work of Peregrine (1967). NSWMs possess some distinctive advantages that make them very suitable for modelling flows occurring in shallow depths (Brocchini et al., 2001). We perform our study with the nonlinear shallow-water wave model. Since tsunami wavelengths are much larger than the sea depth, tsunamis are considered as shallow-water waves following the long-wave theory.

Long-wave theory is used (where the ratio of water depth to wavelength is small) in which the vertical acceleration of water particles is negligible compared with the gravitational acceleration, and the hydrostatic pressure approximation is used. The nonlinear terms are kept for their use where needed, which is the case in very shallow water (from the tsunami point of view). In addition, we are interested in this investigation on near-field tsunamis, that is, those whose propagation distance is less than $200 \mathrm{~km}$. Therefore, Cartesian coordinates can be used. The vertical integrated governing equations (Dean and Dalrymple, 1984) can be written (after setting the momentum correction factors equal to unity, with Coriolis effect omitted):

$$
\begin{aligned}
& \frac{\vartheta M}{\vartheta t}+\frac{\vartheta}{\vartheta \chi}\left(\frac{M^{2}}{D}\right)+\frac{\vartheta}{\vartheta y}\left(\frac{M N}{D}\right)+g D \frac{\vartheta \eta}{\vartheta \chi}+\frac{g k^{2}}{D^{7 / 3}} M \sqrt{M^{2}+N^{2}}=0 \\
& \frac{\vartheta N}{\vartheta t}+\frac{\vartheta}{\vartheta \chi}\left(\frac{N^{2}}{D}\right)+\frac{\vartheta}{\vartheta y}\left(\frac{M N}{D}\right)+g D \frac{\vartheta \eta}{\vartheta \chi}+\frac{g k^{2}}{D^{7 / 3}} N \sqrt{M^{2}+N^{2}}=0 \\
& \frac{\vartheta \eta}{\vartheta t}+\frac{\vartheta M}{\vartheta \chi}+\frac{\vartheta N}{\vartheta y}=0,
\end{aligned}
$$

where $\eta$ is the water surface elevation, $t$ is time, $x$ and $y$ are the horizontal coordinates in zonal and meridional directions, and $M$ and $N$ are the discharge fluxes in the horizontal plane along $x$ and $y$ coordinates given by:

$$
\begin{aligned}
& M=U(h+\eta)=U D \\
& N=V(h+\eta)=V D
\end{aligned}
$$

where $U$ and $V$ are the vertically averaged horizontal particle velocities and $D=h(x, y)+\eta$ is the total water depth, $h(x, y)$ is the undisturbed basin depth, $g$ is the gravity acceleration, and $k$ is the bottom friction coefficient. For the simulation reported here and considering the prevailing bottom morphological features, $k$ has been set equal to 0.025 (Fujima, 2001).

For tsunami propagation, the numerical model employed in this study was developed by N. Shuto and F. Imamura, namely of the Numerical Analysis Model for Investigation of Near field Tsunamis version 2 (TUNAMI-N2). This is one of the key tools for the developing studies for propagation and coastal amplification of tsunamis in relation to different initial conditions. It solves nonlinear shallow water equations in Cartesian coordinates using the leap-frog scheme of finite differences. Also, a similar methodology is used in the numerical model of the method of splitting tsunami (MOST) developed by Titov and Synolakis (1998). These are the only two existing nonlinear shallow water codes, validated with laboratory and field data (Yeh et al., 1996).

In this investigation, we use bathymetric data with a grid size of $87 \mathrm{~m}$. The total number of grid points in the computational domain was 8055799 consisting of $2741 \times 2939$ points. The time step is selected as 0.28 s to satisfy the CFL stability condition (e.g. Tselentis et al., 2006; Goto and Ogawa, 1992). The duration time of wave propagation was $60 \mathrm{~min}$.

Our simulations have two classes of products: we first compute the snapshots of the sea surface displacement all over the grid at time intervals of $4 \mathrm{~min}$. Second, we compute the time series of water surface elevations (mareograms or virtual gauges) at eleven selected locations along the Ionian shorelines possessing increased tsunami hazard due to recent tourist development.

\section{Discussion of the results}

Figure 3 presents the snapshots of the water surface displacement at 4-min intervals up to $20 \mathrm{~min}$, for Filiatra fault (source 1) and Fig. 5 presents the corresponding mareograms at the 12 most important tourist resorts along the Ionian shoreline (Fig. 4). This potential tsunami source is an offshore fault recognised by a "clustering" of the seismicity; it has a NNW-SSE direction almost parallel to the nearby Peloponnesus coast, and it is a thrust fault with a length $L=70 \mathrm{~km}$ and a width $W=45 \mathrm{~km}$ (Papazachos and Papazachou, 1997; Papanikolaou et al., 2007). Several moderate to strong earthquakes have been attributed to this fault; in 1886 this was the source of the $M=7.5$ event (estimated from the observed maximum intensity $X$ of MM scale), also the 1899 Kyparissia ( $M=6.5$; Papazachos and Papazachou, 1997) and the 1919 Kyparissia ( $M=6.3$; Papazachos and Papazachou, 1997) earthquakes, have been related to this fault.

As we can see from Fig. 3, after 4 min the wave arrives at Pilos city coastal area, where it reaches a maximum amplitude of $1.6 \mathrm{~m}$ after $6 \mathrm{~min}$. After $8 \mathrm{~min}$, the wave arrives at Proti island where it reaches the greatest amplitude observed 

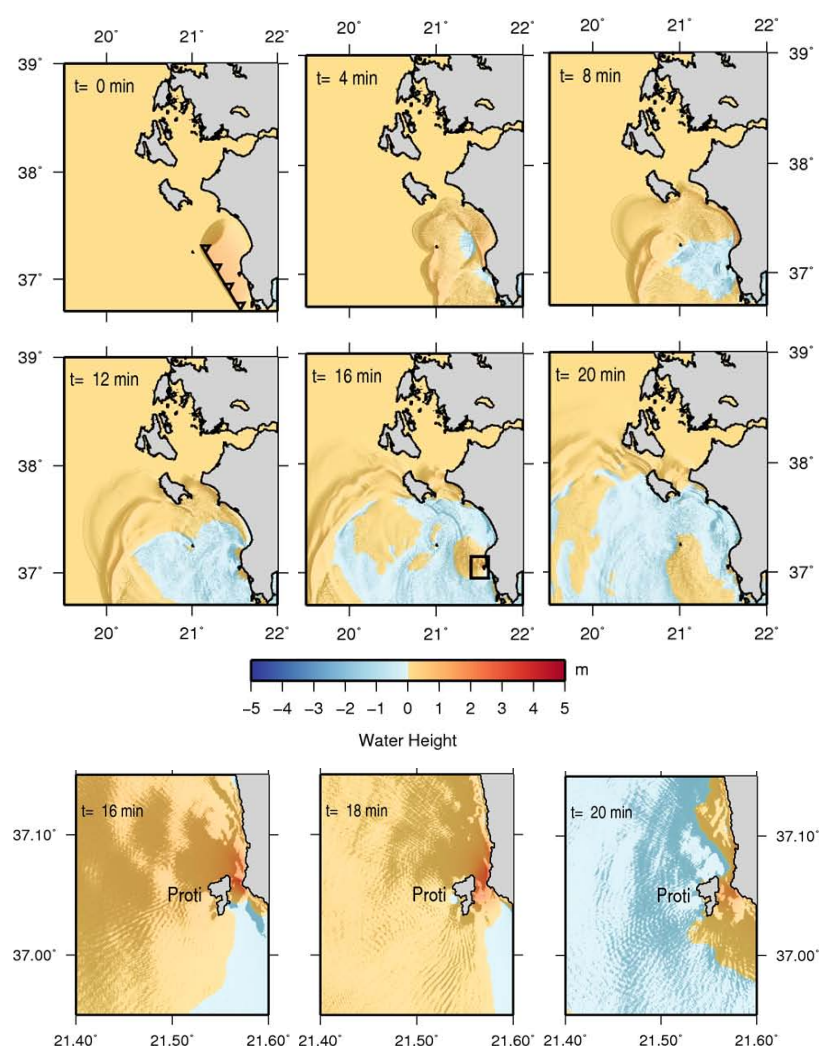

Fig. 3. Snapshots of the tsunami propagation from the source 1 (Filiatra fault) at 4-min intervals. The propagation close to Proti islet is presented in the last row, at a higher magnification.

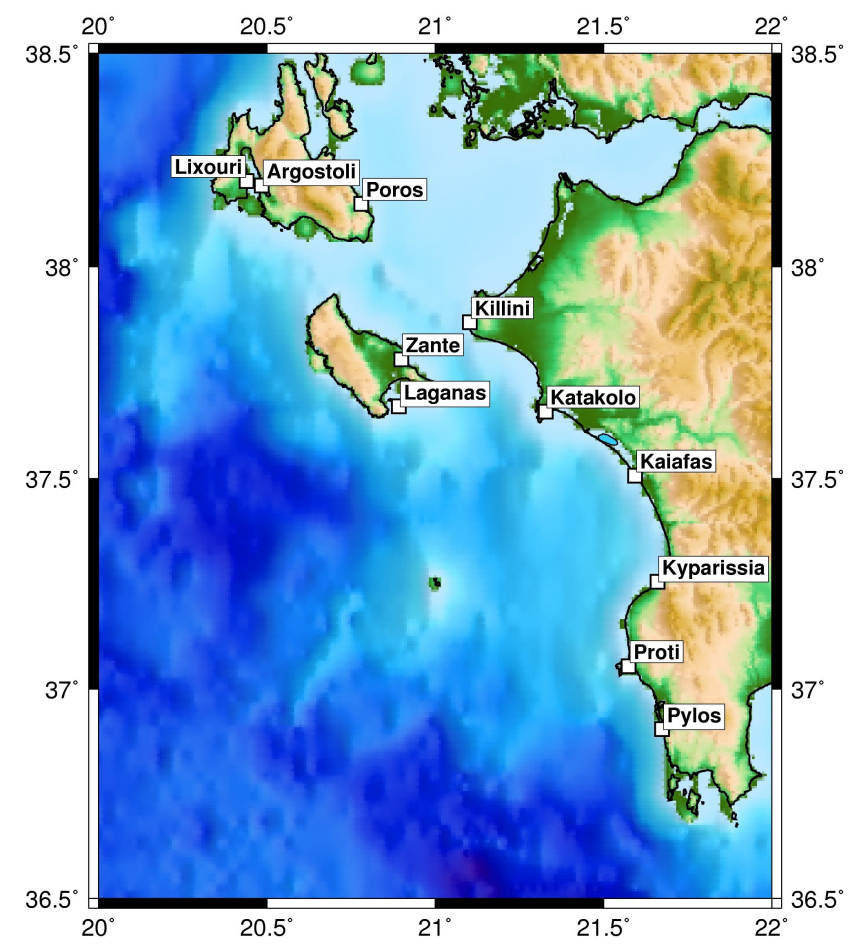

Fig. 4. Locations of the gouges considered in the present investigation, which represent the most populated tourist resorts along the Ionian shoreline.

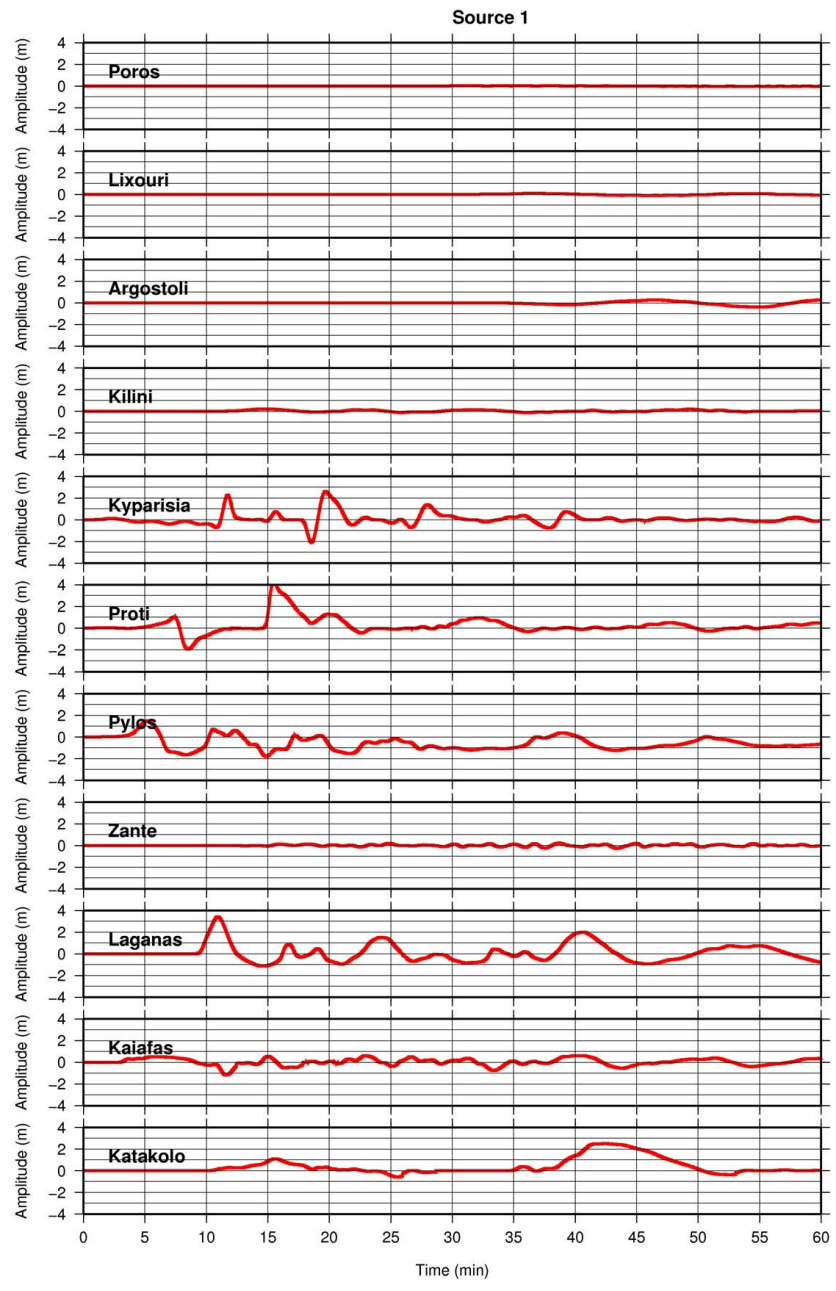

Fig. 5. Calculated mareograms at the locations shown in Fig. 4, for source 1 (Filiatra fault).

in this simulation, $4 \mathrm{~m}$ at $16 \mathrm{~min}$. For this reason, we focus in this area depicting tsunami propagation snapshots at a higher magnification.

After $9 \mathrm{~min}$, the wave arrives at the tourist resort of Laganas bay in Zakynthos, where it reaches a maximum amplitude of $3.5 \mathrm{~m}$ after $11 \mathrm{~min}$. This is a heavily populated region during the summer with thousands of tourists in the coastal zone and needs specific attention and tsunami risk reduction planning.

For all the other locations, wave amplitudes are relatively small with the exception of Kyparisia region where $13 \mathrm{~min}$ and 19 min after the activation of the fault it reaches an amplitude of $3 \mathrm{~m}$. This is also a heavily populated tourist area during the Summer season.

Figure 6 shows snapshots of the tsunami propagation corresponding to the activation of the Zakynthos fault (source 2). The corresponding mareograms at the locations depicted in Fig. 4 are presented in Fig. 7. This potential source is mapped according to seismological evidence (FAUST 


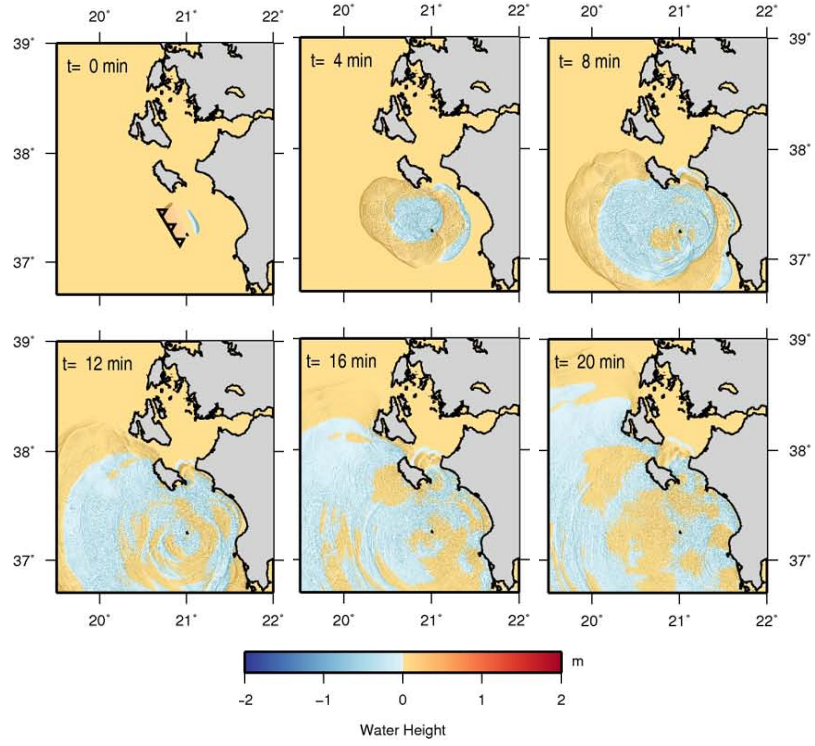

Fig. 6. Snapshots of the tsunami propagation from the source 2 (Zakynthos fault) at 4-min intervals.

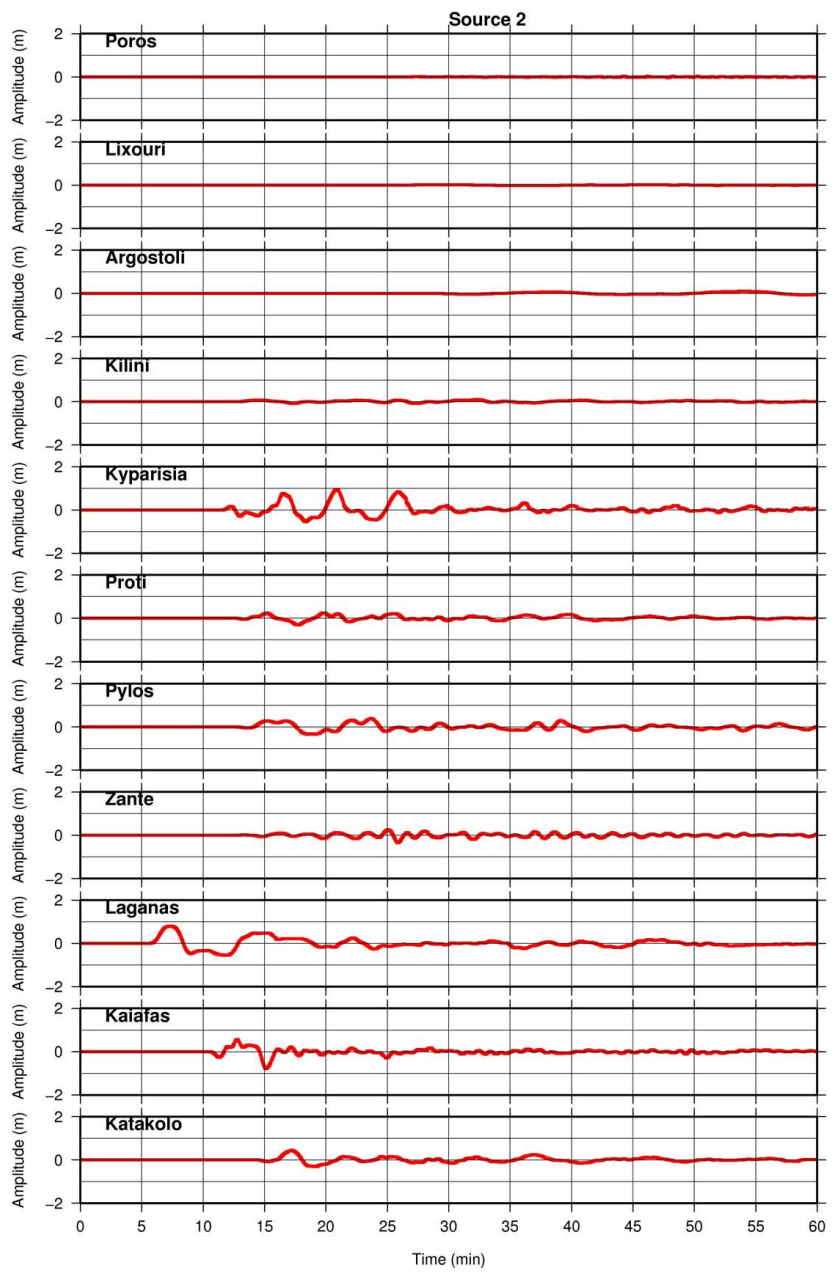

Fig. 7. Calculated mareograms at the locations shown in Fig. 4, for source 2 (Zakynthos fault).

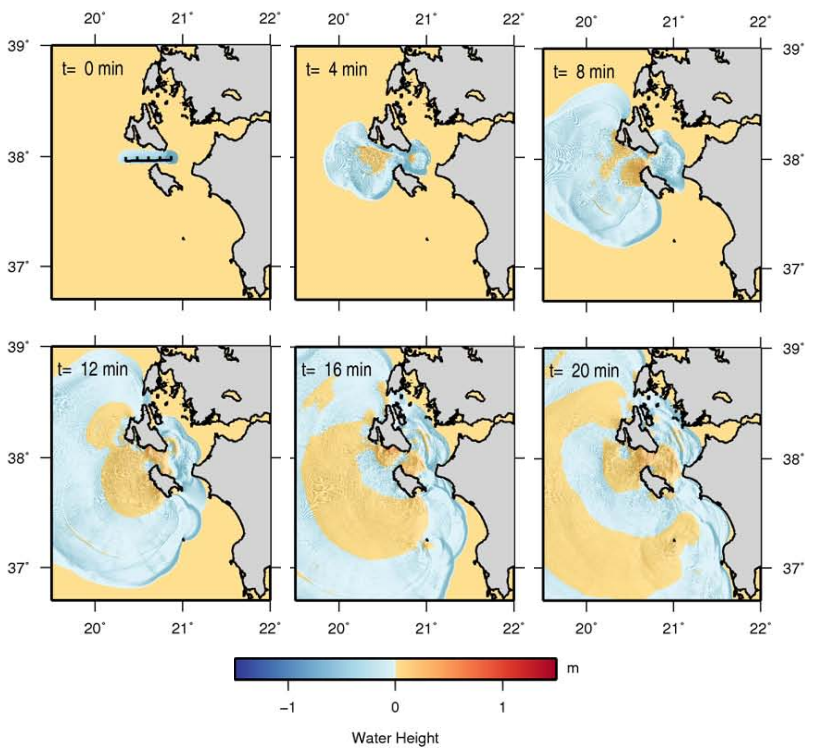

Fig. 8. Snapshots of the tsunami propagation from the source 3 (Cephalonia South fault) at 4-min intervals.

database) proposed by Ambraseys and Jackson (1990) on the basis of the 1958 earthquake with a magnitude $M=7.0$. It is a thrust fault with a length $L=35 \mathrm{~km}$ and a width $W=22 \mathrm{~km}$. The focal mechanism adopted by the FAUST database is consist with focal mechanisms calculated from recent earthquakes located in the area South of Zakynthos.

Judging from the above figures, we can see that the activation of this particular source has little effect on the tsunami hazard of the region under investigation. The greatest wave amplitudes are reached at Kyparisia bay where they become $1 \mathrm{~m}$ at 16,21 and $25 \mathrm{~min}$ after the source activation. Also, at the Lagana bay region, they reach an amplitude of $0.9 \mathrm{~m}$ 7 min after the activation of the source.

Figure 8 shows the snapshots of the tsunami propagation corresponding to the activation of the Cephalonia South fault (source 3 ). The corresponding mareograms at the locations depicted in Fig. 4 are presented in Fig. 9. This source is located in the sea area North of Zakynthos island. According to Monopolis and Bruneton (1982) the northern flank of Zakynthos is steep and is affected by large normal faulting. It is suggested that this normal fault caused the 1554 earthquake, while the maximum expected magnitude from this source is $M=6.5$ (Stucchi et al., 2001).

In this case, we see that the activation of Cephalonia South source possesses no significant tsunami hazard in the region, since all the wave amplitudes are below $0.5 \mathrm{~m}$. The greatest amplitude is observed at Laganas bay, where it becoms $0.4 \mathrm{~m}$.

Sources 3 and 4 (Cephalonia South and North faults) are mapped in Fig. 1 according to Lagios et al. (2007), where it is mentioned that major faults having the length of several tenths of kilometres in the marine area between Cephalonia 


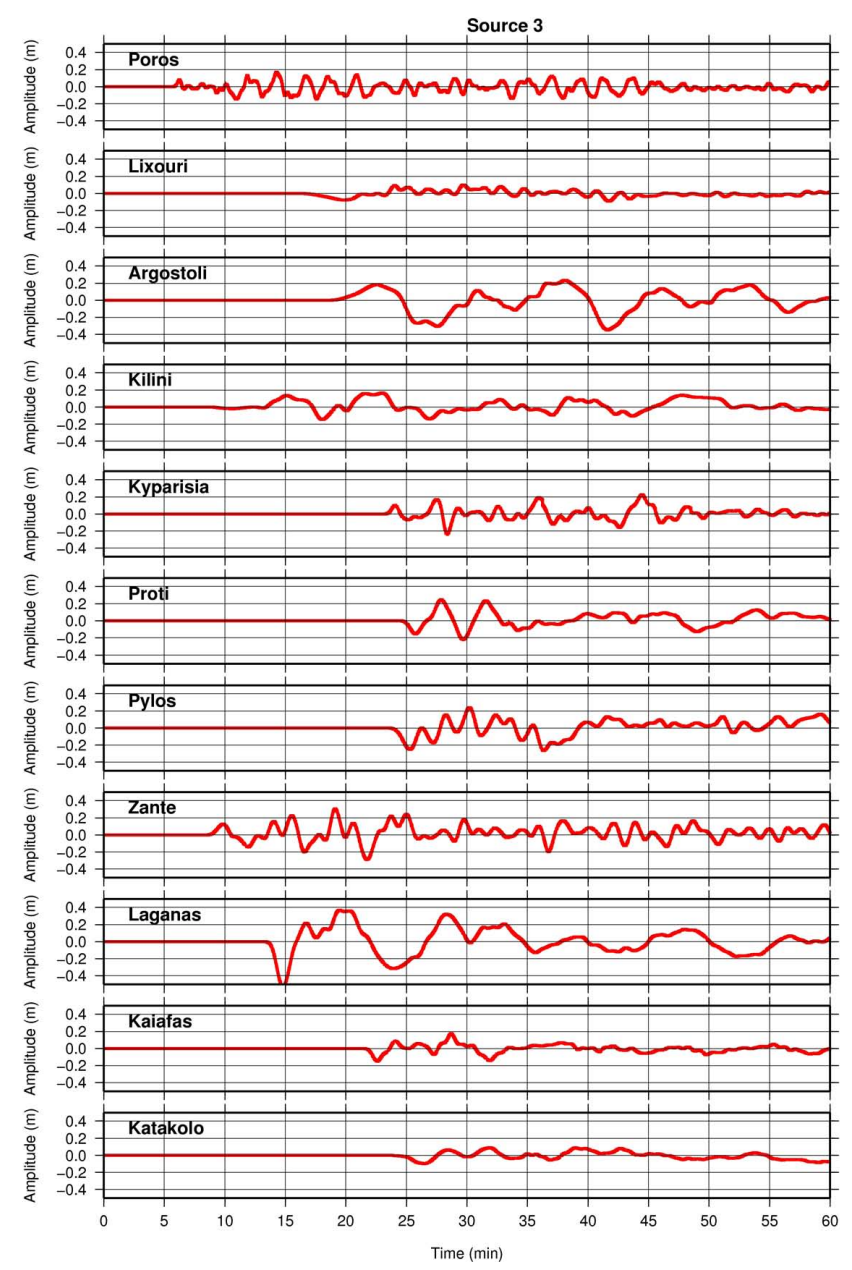

Fig. 9. Calculated mareograms at the locations shown in Fig. 4, for source 3 (Cephalonia South fault).

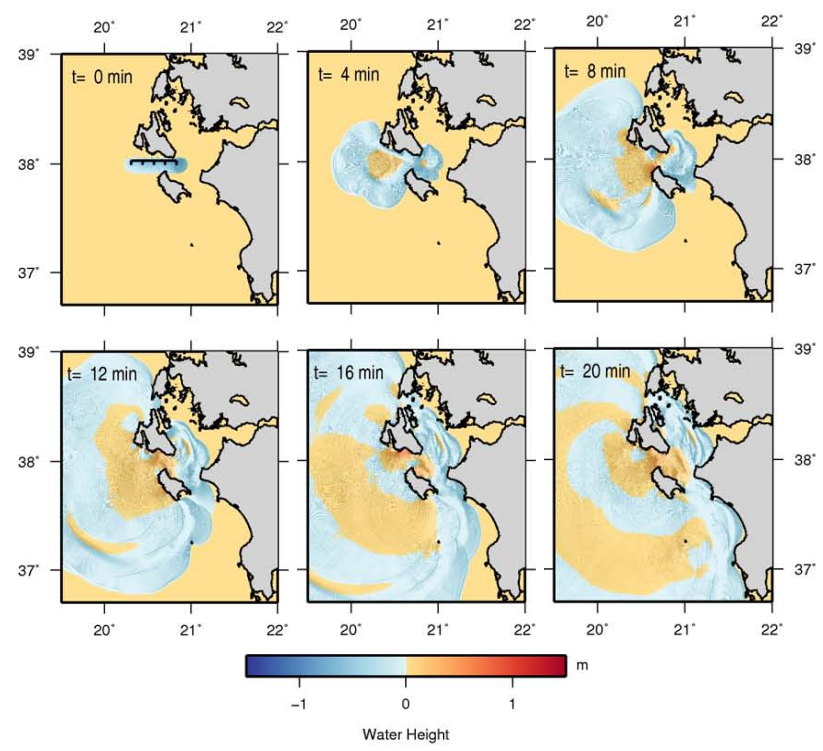

Fig. 10. Snapshots of the tsunami propagation from the source 4 (Cephalonia North fault) at 4-min intervals.

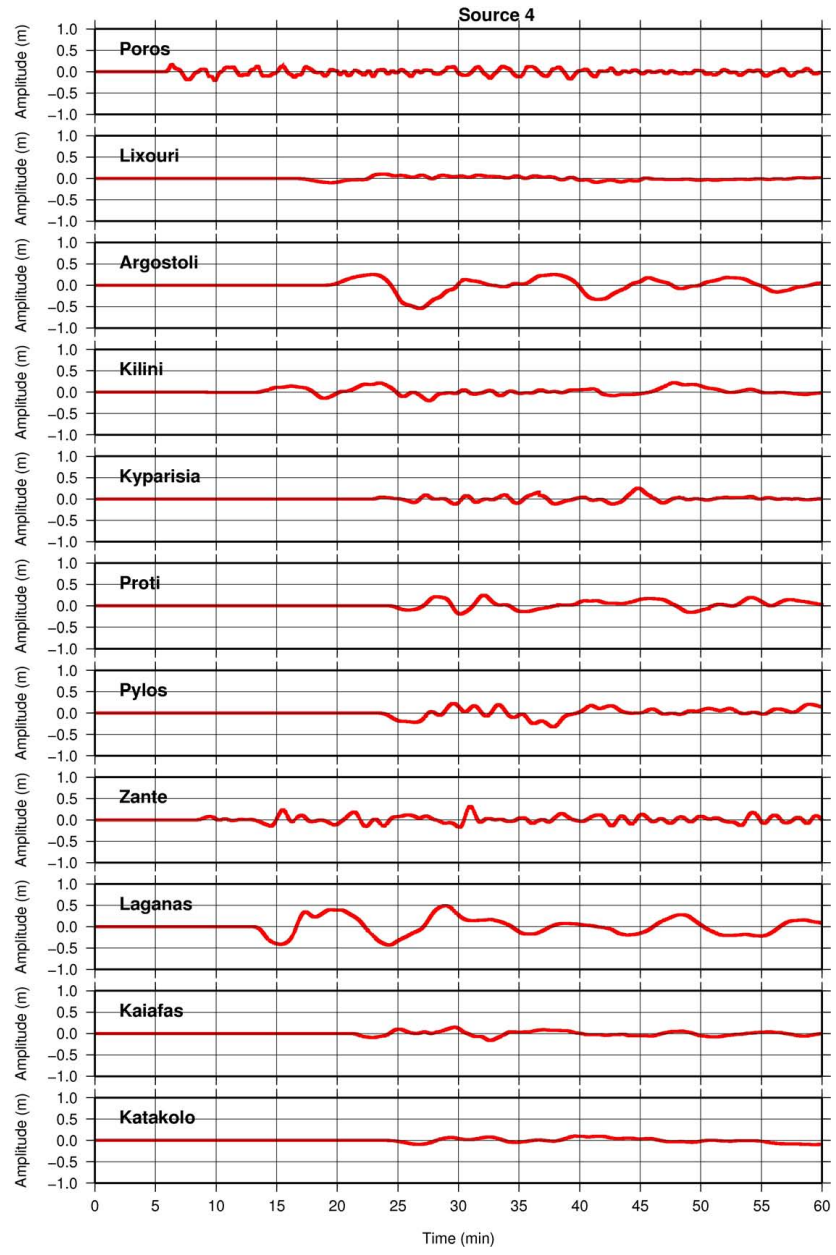

Fig. 11. Calculated mareograms at the locations shown in Fig. 4, for source 4 (Cephalonia North fault).

and Zakynthos could control the tectonic movements in the area. Source 4 represents a normal fault, which is located in the coastal area of Cephalonia. The fault dimensions were computed according to empirical relationships (Papazachos and Papazachou, 1997). FAUST database (after Stucchi et al., 2001) suggests this source as the causative fault of the 1636 earthquake $(M=7.1)$.

Figure 10 shows snapshots of the tsunami propagation corresponding to the activation of the Cephalonia North fault (source 4). The corresponding mareograms at the locations depicted in Fig. 4 are presented in Fig. 11.

Judging from the above figures, we can see that the results obtained are similar to those corresponding to the activation of source 3. The greatest wave amplitude is $0.5 \mathrm{~m}$ and is reached at Laganas Bay at 20 and $28 \mathrm{~min}$ after the source activation. 


\section{Conclusions}

The main objective of this work was the study of possible tsunamis in the Ionian Sea. This was carried out by using a forward modelling approach, that is, by running numerical tsunami simulations, relative to different genetic mechanisms that seem plausible on the basis of the present knowledge of the seismotectonics of the region.

Special emphasis was given to eleven tourist resorts, where we computed the corresponding activation of each of the four sources, mareograms. From all the examined sources, only source 1 possesses a serious threat, causing a wave propagation amplitude that reaches up to $4 \mathrm{~m}$ at two locations. Since these locations are heavily populated during the summer season, the need for special tsunami risk mitigation measures is obvious.

Acknowledgements. We thank M. E. Contadakis for his help. Also C. Makropoulos is acknowledged for his useful comments. The contribution of two anonymous reviewers is appreciated.

Edited by: M. E. Contadakis

Reviewed by: two anonymous referees

\section{References}

Ambraseys, N. N.: The seismic sea wave of July 9, 1956, in the Greek Archipelago, J. Geophys. Res., 65(4), 1257-1265, 1960.

Ambraseys, N. N.: Data for the Investigation of the Seismic Sea Waves in the Eastern Mediterranean, B. Seismol. Soc. Am., 52(4), 895-913, 1962.

Ambraseys, N. N. and Jackson, J. A.: Seismicity and associated strain of central Greece between 1890 and 1988, Geophys. J. Int., 101, 663-708, 1990.

Antonopoulos, J. A.: Data from the investigation of seismic seawave events in the eastern Mediterranean from the birth of Christ to $1980 \mathrm{AD}$ (six parts), Ann. Geophys., 33, 141-248, 1980, http://www.ann-geophys.net/33/141/1980/.

Antonopoulos, J. A.: Tsunamis of Eastern Mediterranean from Antiquity until Today, Athens, 1973 (in Greek).

Brocchini, M., Bernetti, R., Mancinelli, A., and Albertini, G.: An efficient solver for nearshore flows based on the WAF method, Coast. Eng., 43, 105-129, 2001.

Comer, R. P.: Tsunami generation: a comparison of traditional and normal mode approaches, Geophys. J. Roy. Astr. S., 77, 29-41, 1984.

Dean, R. G. and Dalrymple, R. A.: Water Wave Mechanics for Engineers and Scientists, World Scientific Publishing Co., Singapore, 353 pp., 1984.

DeMets, C., Gordon, R. G., Argus, D. F., and Stein, S.: Current plate motions, Geophys. J. Int., 101, 425-478, 1990.

Fujima, K.: Long wave propagation on large roughness, ITS Proceedings, Session 7, no. 7-22, 891-895, 2001.

Galanopoulos, A.: La sismicité de l'Achaie et des régions voisines de Missolonghi et de Naupacte, Leipzig, Gerl. Beitr. Geophys., 53, 203-212, 1938 (in French).
Galanopoulos, A.: Die Seismizität der Insel Leukas; Allgemeine historische Uebericht, Leipzig, Gerl. Beitr. Geophys., 62(4), 256-263, 1952 (in German).

Galanopoulos, A.: A catalogue of shocks in Greece with I->VI or M>5 for the years 1801 to 1958 , Publications, Seismological Laboratory, University of Athens, Athens, 1960.

Galanopoulos, A.: A catalogue of shocks in Greece with i>=VII for the years prior to 1800 , Publications, Seismological Laboratory, University of Athens, Athens, 1961.

Goto, C. and Ogawa, Y.: Numerical method of tsunami simulation with the leap-frog scheme, Dept. of Civil Engineering, Tohoku University, Translated from TIME project by N. Shuto, 1992.

Goto, C., Ogawa, Y., Shuto, N., and Imamura, N.: Numerical method of tsunami simulation with the leap-frog scheme (IUGG/IOC Time Project), IOC Manual, United Nations Educational Scientific and Cultural Organization (UNESCO), No. 35, 1997.

Haslinger, F., Kissling, E., Ansorge, J., Hatzfeld, D., Papadmitriou, E., Karakostas, V., Makropoulos, K., Kahle, H-G., and Peter, Y.: 3D crustal structure from local earthquake tomography around the Gulf of Arta (Ionian region, NW Greece), Tectonophysics, 304, 201-218, 1999.

Hoff, K.: Chronik der Erdbeben und Vulkan-Ausbrüeche, mit vorausgehender Abhandlung über die Natur dieser Erscheinungen, Gesch. Ueberlieferung nachgew natürl. Veränder. Erdoberfläche, Parts 4 and 5, Gotha, 1841 (in German).

Jackson, J. and McKenzie, D.: Rates of active deformation in Aegean Sea and surrounding regions, Basin Res., 1, 121-128, 1988.

Jackson, J.: Active tectonics of the Aegean region, Annu. Rev. Earth Pl. Sc., 22, 239-271, 1994.

Kahle, H.-G., Müller, M. V., Mueller, S., Veis, G., Billiris, H., Paradissis, D., Drewes, H., Kaniuth, K., Stuber, K., Tremel, H., Zerbini, S., Corrado, G., and Verrone, G.: Monitoring West Hellenic Arc Tectonics and Calabrian Arc Tectonics ("WHAT A CAT"') using the Global Positioning System, in: Contribution of Space Geodesy to Geodynamics, edited by: Smith, D. and Turcotte, D., AGU Geodyn. Ser., 23, 417-429, 1993.

Lagios, E., Sakkas, V., Papadimitriou, P., Parcharidis, I., Damiata, B. N., Chousianitis, K., and Vassilopoulou, S.: Crustal deformation in the Central Ionian Islands (Greece): Results from DGPS and DInSAR analyses (1995-2006), Tectonophysics, 444(1-4), 119-145, 2007.

Legg, M. R., Eeeri, M., Borrero, J. C., and Synolakis, C. E.: Tsunami hazards associated with the Catalina fault in Southern California, Earthq. Spectra, 20(3), 917-950, 2004.

Liu, P. L., Synolakis, C. E., and Yeh, H.: Impressions from the First International WorkShop on Long Wave Runup, J. Fluid Mech., 229, 675-688, 1991.

Liu, Y., Santos, A., Wang, M. S., Shi, Y., Liu, H., and Yuen, D.: Tsunami hazard along Chinese coast from potential earthquakes in South China Sea, Phys. Earth Planet. In., 163, 233-244, 2007.

Makropoulos, C. and Burton, P. W.: A catalogue of the seismicity in Greece and adjacent areas, Geophys. J. Roy. Astr. S., 65, 741762, 1981.

Mallet, R.: Report on the facts of earthquake phaenomena, British Association for the Advancement of Science, Part 1, 185089 pp.; Part 2, 1852, 212 pp.; Part 3, 1854326 pp.; Part 4, 1858, 136 pp., J. Taylor (Publisher), 1850-1858. 
Mansinha, L. and Smylie, D. E.: The displacement fields of inclined faults, B. Seismol. Soc. Am., 61, 1433-1440, 1971.

Mariolakos, I., Papanikolaou, D., and Lagios, E.: A neotectonic geodynamic model of Peloponnese based on morphotectonics, repeated gravity measurements and seismicity, Geol. Jb. B, 50, 3-17, 1985.

Monopolis, D. and Bruneton, A.: Ionian Sea (Western Greece): its structural outline deduced from drilling and geophysical data, Tectonophysics, 83, 227-242, 1982.

Noomen, R., Springer, T., Ambrosius, B., Herzberger, K., Kuijper, D., Mets, G., Overgaauw, B., and Wakker, K.: Crustal deformations in the Mediterranean area computed from SLR and GPS observations, J. Geodyn., 21(1), 73-96, 1995.

Okada, Y.: Surface deformation due to shear and tensile faults in half space, B. Seismol. Soc. Am., 75, 1135-1154, 1985.

Okal, E. A.: Mode-wave equivalence and other asymptotic problems in tsunami theory, Phys. Earth. Planet. In., 30, 1-11, 1982.

Ornstein, B.: Das Erdbeben fon Vostiza Ausland, MünchenStuttgart, 62, p. 453, 1889 (in German).

Papanikolaou, D., Fountoulis, I., and Metaxas, C.: Active faults, deformation rates and Quaternary paleogeography at Kyparissiakos Gulf (SW Greece) deduced from onshore and offshore data, Quatern. Int., 171-172, (SPEC. ISS.), 14-30, 2007.

Papazachos, B. C., Koutitas, Ch., Hatzidimitriou, P. M., Karacostas, B. G., and Papaioannou, Ch. A.: Source and short-distance propagation of the July 9, 1956 southern Aegean tsunami, Mar. Geol., 65, 343-351, 1985.

Papazachos, B. C., Koutitas, Ch., Hatzidimitriou, P. M., Karacostas, B. G., and Papaioannou, Ch. A.: Tsunami hazard in Greece and the surrounding area, Ann. Geophys. 4, 79-90, 1986.

Papazachos, B. C. and Dimitriu, P. P.: Tsunamis in and near Greece and their relation to the earthquake focal mechanisms, Nat. Hazards, 4, 161-170, 1991.

Papazachos, B., Kiratzi, A., and Papadimitriou, E.: Regional focal mechanisms for earthquakes in the Aegean Area, Pure Appl. Geophys, 136, 407-420, 1991.

Papazachos, B. and Papazachou, C.: The Earthquakes of Greece, Ziti Publication Co., Thessaloniki, 304 pp., 1997.
Papoulia, J., Makris, J., Tsambas, A., and Fasoulaka, Ch.: Seismic Deformation in the South Western Hellenic Arc: Preliminary Results from Active and Passive Seismic Observations, Bull. Geol. Soc. Greece, in press, 2008.

Peregrine, D. H.: Long waves on a beach, J. Fluid Mech., 27, 815827, 1967.

Sieberg, A.: Untersuchungen über Erdbeben und Bruchschollenbau im Östlichen Mittelmeergebiet, MedizinischNaturwissenschaftlichen Gesellschaft, 18, 159-273, 1932.

Soloviev, S. L., Solovieva, O. N., Go, C. N., Kim, K. S., and Shchetnikov, N. A.: Tsunamis in the Mediterranean Sea 2000 B.C.2000 A.D., in: Advances in Natural and Technological Hazards Research, Volume 13, Kluwer Academic Publishers, Dordrecht, Netherlands, 237 pp., 2000.

Stucchi, M., Albini, P., Camassi, R., Musson, R. M. W., and Tatevossian, R.: Main results of the Project BEECD "A Basic European Earthquake Catalogue and a Database for the Evaluation of Long-term Seismicity and Seismic Hazard”, in: Tools for planning in seismic areas: integrated approaches and data availability, edited by: Yeroyanni, M., Margottini, C., and Zonno, G., European Commission, Brussels, Luxembourg, III, 24 pp., 2001.

Taymaz, T., Jackson, J. A., and Westway, R.: Earthquake mechanisms in the Hellenic Trench near Crete, Geophys. J. Int., 102, 695-732, 1990.

Thomas, A. M.: Poly 3D: a three-dimensional, polygonal element, displacement discontinuity boundary element computer program with applications to fractures, faults and cavities in the Earth's crust, M.Sc. thesis, Stanford University, 1993.

Titov, V. V. and Synolakis, C. E.: Numerical modeling of tidal wave runup, J. Waterw. Port C.-ASCE, 124(4), 157-171, 1998.

Tselentis, G-A., Gkika, F., and Sokos, E.: Tsunami hazards associated with the Perachora fault at eastern Corinth gulf, Greece, B. Seismol. Soc. Am., 96(5), 1649-1661, 2006.

Vidal, L.: Sur le tremblement de terre du 27 Août 1886 en Grece, Comptes Rendus de l'Acaddmie de Sciences, Paris, 103, 563565, 1886 (in French).

Yeh, H., Liu, P., and Synolakis, C. (Eds.): Long-wave run-up models, Proceedings of the international workshop, Friday Harbor, USA, 1995, World Scientific publishers Co, Singapore, 1996. 